\title{
ACTIVITY OF YOUNG PEOPLE WITH DISABILITIES IN THE DIGITAL ENVIRONMENT
}

\author{
Svetlana Usca \\ Rezekne Academy of Technologies, Latvia \\ Aija Vindece \\ Rezekne Academy of Technologies, Latvia
}

\begin{abstract}
Young people with disabilities are often socially inactive because their participation in social and economic processes is limited. In order to reduce this, digital technologies are important, the use of which allows any individual to engage in various types of activities (educational, cultural, economic, etc.).

Objective of the paper: to analyze the results of exploratory research on the activity of young people with disabilities in the digital environment. Methods: questionnaire, focus discussion.

The results suggest that support and education measures require a differentiated approach, in which it is important to determine the level of interests and digital competence of each young person with disabilities, clearly set goals that can be adapted to individual needs, tasks according to individual abilities/skills. This means working in small groups or individually.

Keywords: young people with disabilities, digital technologies, activity in the digital environment.
\end{abstract}

\section{Introduction}

Young people with limited adaptive behavior, impaired language development and low socio-economic status are at high risk of poor socialization (Koskentausta et al., 2007). This can be reduced through the use of digital technologies and social media, as their rapid growth and accessibility contribute to social participation and offer new means of communication for people with disabilities (Wang et al., 2017). New paradigms are being used to set up platforms for cooperation and education to meet the needs of people with disabilities, focusing on making information on social networks accessible to people with disabilities, creating special platforms for exchange information, where people with disabilities can ask questions, but the responsible persons (policy makers, representatives of health and social institutions, etc.) can provide answers in order to ensure an environment for friendly social interaction (García-Betances et al., 2016; Raghavendra et al, 2015; Luo et al., 2015; Wang, Min, \& Han, 2016; Wang et al., 2017). The use of such platforms can help reduce the information gap between individuals and the surrounding community and institutions (GarcíaBetances et al., 2016). 
Despite many technological innovations, people with disabilities, including young people with disabilities, are under-represented on social media (Media Access Australia, 2012), and it is important to encourage and teach them to use social networks to express themselves (Hemsley et al., 2017).

According to the data of the State Medical Commission for the Assessment of Health Condition and Working Ability, in 2019, 185548 adult persons with disabilities were registered in Latvia, i.e. $9.66 \%$ of the total population of the country. There are 8025 persons aged 18 to 29 (young people) ( $4.2 \%$ of the total number of disabled persons, including 1474 persons are group I disabled persons, 3045 persons are group II disabled persons and 3506 persons are group III disabled persons) (Labklājības Ministrija, 2019; Centrālā statistikas pārvalde, 2019). Despite the relatively large number of young people with disabilities, there is a lack of research in Latvia on young people with disabilities and social media, and habits of the use of social media by young people with disabilities. These issues are integrated into wider research on employment, discrimination, inclusion of people with disabilities, and the level of awareness.

The objective of the paper is to analyze the results of exploratory research on the activity of young people with disabilities in the digital environment.

Methods: questionnaire, focus discussion.

\section{Methodology}

Research included a survey of young people with disabilities and focus discussions.

Research was conducted with support of the ERASMUS + Strategic Partnership project "Social Media Marketing Skills for Fostering the Inclusion and Employability of Young People with Disabilities - SMM4WIN", No. 20192-PL01-KA205-066133. The questionnaire developed within the project was used.

In the questionnaire, 14 out of 15 questionnaires were recognized as valid. 10 participants are young people with disabilities aged 21 to 30, 4 did not want to indicate age. 5 respondents are hearing impaired, 3 - disabled due to various diseases, 6 - young people with mental disorders. 8 respondents are men, 6 respondents - women. 5 respondents have secondary education, one respondent has a Bachelor's degree, and the others have primary education. 12 respondents have no work experience, 1 respondent worked less than a year, one worked from one year to 5 years. 10 respondents are unemployed, 4 are currently studying.

As several respondents have mental disorders, their questionnaire was conducted individually, explaining the questions in the questionnaire.

The results obtained in the questionnaire were coded and processed in the SPSS program. Nonparametric methods were used. 
In order to better understand the use of the virtual environment by young people with disabilities, focus discussions were organized with young people who participated in the questionnaire and their content analysis was performed, as a result of which the concepts were identified.

\section{Results and Discussion}

The content analysis of focus discussions of young people with disabilities allows to conclude that young people with disabilities spend a lot of time on the Internet and admit that it ..lures, takes a lot of time, .. does not feel the time and how long they have spent at the computer. This is also confirmed by the results of the questionnaire. Young people with disabilities spend a lot of time online every day: 4 respondents - more than 6 hours, 3 respondents - 5 hours, 1 respondent 4 hours, 4 respondents - 1-3 hours, 1 respondent - less than an hour, one respondent could not answer the question.

The respondents were asked to rate three digital technologies that are important for personal empowerment and professional development. The answers are summarized in Figure 1.

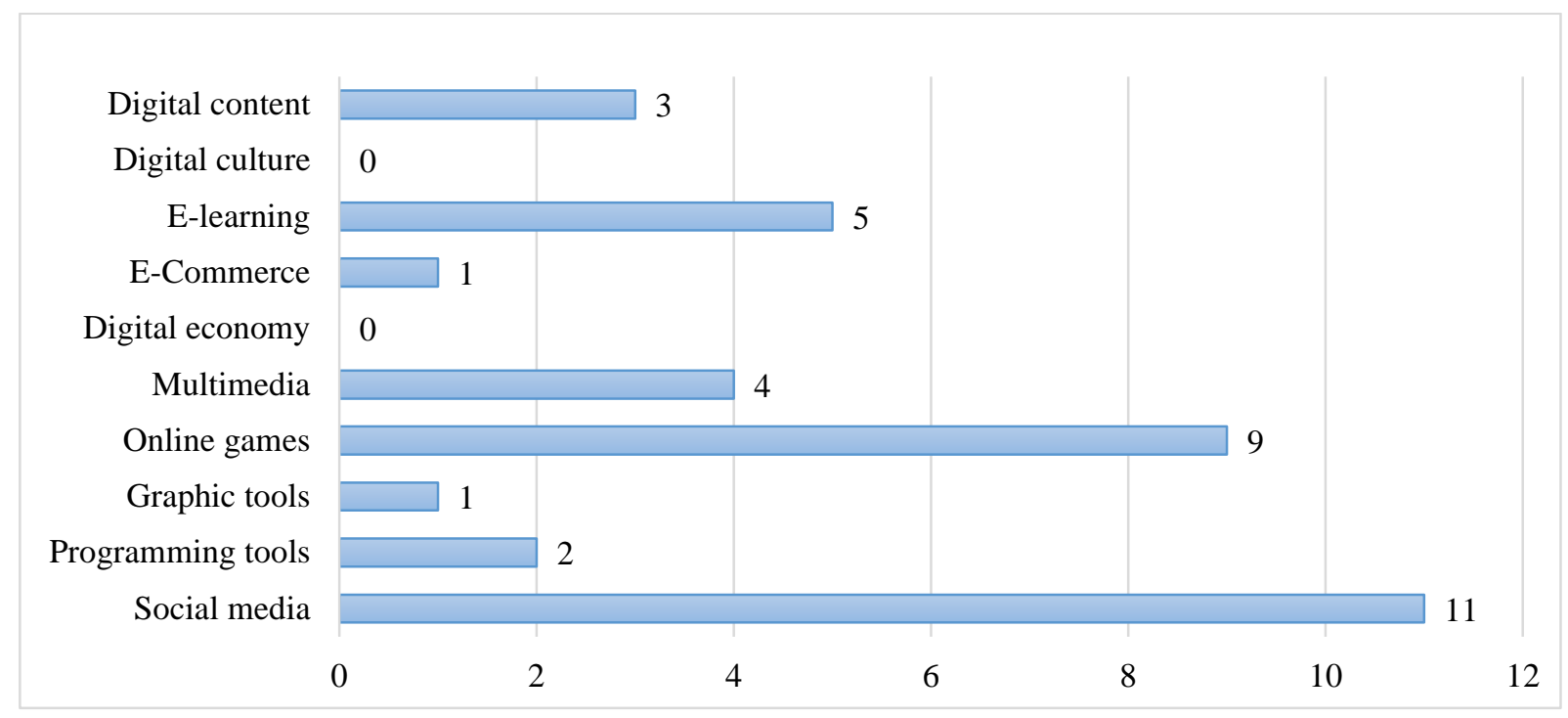

Figure 1 The most significant digital technologies (respondents' assessment)

Figure 1 shows that the use of social media dominates. Social media promotes social activity (Forrester-Jones et al., 2004), and the term Augmentative and alternative communication (AAC) is used (Hemsley et al., 2017). In this context, there are, for example, research on the use of social media, the positive and negative aspects of this use in adults with intellectual disabilities (Balandin \& Molka Danielsen, 2015), autism spectrum disorders (ASD) (Stendahl \& Balandin, 2015), communication disorders (Paterson \& Carpenter, 2015), acquired brain 
injuries resulting in cognitive communication disorders (Brunner et al., 2019). The role of social media in the daily life and socialization of young people with disabilities is emphasized (Hemsley et al., 2017), and it is believed that young people with disabilities can learn and improve their social connections through social media (Raghavendra et al., 2015). However, individual interviews with social workers show that young people with disabilities have different experiences and habits of using social media: if young people have mental disorders, their interest is limited to games or seeking sexual information, often followed by inadequate response, so access to computers in social centers is often limited.

During the questionnaire, young people with disabilities were asked to rate statements about technology using the Likert scale, where 0 means strongly disagree, 1 - mildly disagree, 2 - neither agree nor disagree, 3 - mildly agree, and 4 strongly agree. The results are summarized in Figure 2.

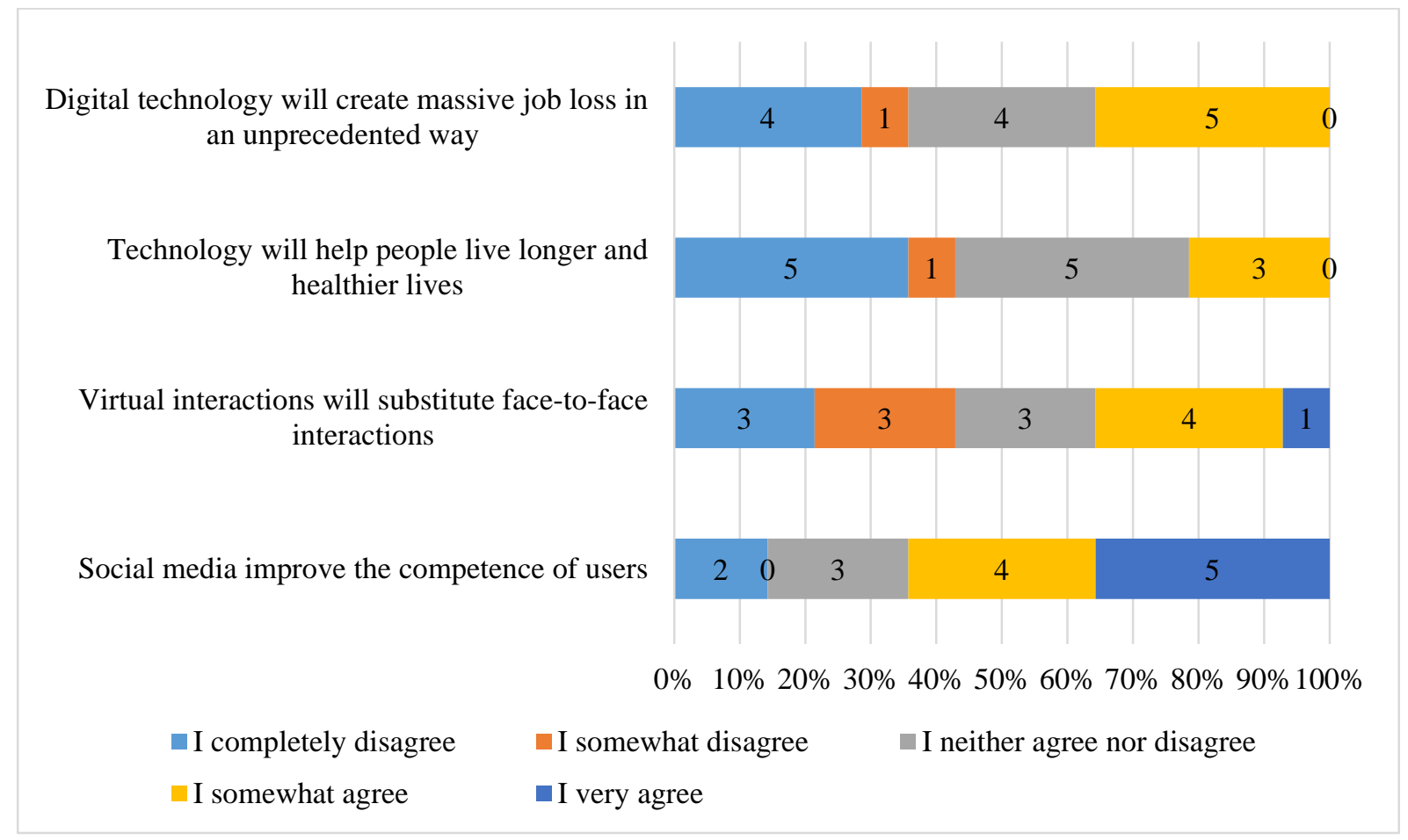

Figure 2 Respondents' assessment of the statements

Using the Mann-Whitney test, the analysis of the responses found statistically significant differences in the assessment of the statements Technologies will help people to live longer and healthier $(\mathrm{p}=.037)$ (young students with disabilities agree more (Mean Rank 11.00) than young unemployed people with disabilities (Mean Rank 6.10)) and Digital technologies will cause huge job losses $(\mathrm{p}=.046)$ (young students with disabilities agree more (Mean Rank 10.88) than young unemployed people with disabilities (Mean Rank 6.15)). 
Spearman's correlation shows that there is a correlation between the assessment of respondent's work experience and e-commerce $(\mathrm{r}=.621, \mathrm{p}=.018)$. The correlation also shows that respondents who consider programming tools important emphasize the importance of e-learning $(\mathrm{r}=.548, \mathrm{p}=.048)$. The correlation was also found between the time spent online on a daily basis and the assessment of the importance of social media $(\mathrm{r}=.666, \mathrm{p}=.009)$ and multimedia $(r=.665, \mathrm{p}=.009)$.

Spearman's correlation test shows that there is a correlation between the assessment of the statement Social media improves the users' competence and the assessment of technologies such as social media $(\mathrm{r}=.697, \mathrm{p}=.006)$ and multimedia $(\mathrm{r}=.735, \mathrm{p}=.003)$.

The assessment of the statement Virtual interaction will replace face-to-face communication correlates with the respondents' work experience ( $\mathrm{r}=.534$, $\mathrm{p}=.049$ ).

The assessment of the statement Social media improves the users' competence correlates with the time respondents spend online on a daily basis $(\mathrm{r}=.867, \mathrm{p}=.000)$.

The result suggests that pay more attention to the experiences of young people with disabilities should be paid in the support and education measures, including their experience in the use of the virtual environment, and to the specific type of disability. The differentiated approach is needed, in which it is important to determine the level of interests and digital competence of each young person with a disability, clearly set goals that can be adapted to individual needs, and tasks depending on individual abilities/skills; this means working in small groups or individually. Events organized for 10 or more disabled people at the same time may prove ineffective.

The content analysis of the focus discussions allowed identifying the positive aspects of the virtual environment:

1. It is an educational environment because:

a) it allows getting the necessary information (..I am looking for information for studies..., .. I read on Wikipedia..., .. I learn English with the help of Youtube...);

b) promotes informal education (..I like to learn something new with the help of Youtube..., .. sometimes I am looking for how to learn something, looking for food recipes...).

2. It promotes socialization because:

a) young people with disabilities can participate in various groups, forums (..I am a member of groups on Facebook..., ..there are forums for the deaf...), thus both gaining information and sharing experiences and opinions; 
b) it promotes communication with close and distant friends, acquaintances, like-minded people (..I use it to communicate with people who are far away..., .. it would be difficult to live without the Internet, there would be no communication...);

c) it allows advertising oneself, personal services (..I advertise my wicker baskets with the help of Faceebook...).

3. It meets the special needs of young people with disabilities (..I learned sign language via the website..., .. there are forums for the deaf..., I watch educational programs where there is translation in sign language .... ..there are 3 websites with subtitles for the deaf...... I can order goods...). It is mentioned several times that the respondents learn to cook various simple dishes, soups, bake pancakes, set a table, etc.

Young people with disabilities associate the use of the Internet, social networks and various websites with entertainment, which can be seen as both a positive and a negative aspect, because young people watch various entertainment programs (.. I mostly watch movies..., cartoons .. I watch entertainment programs on youtube ..., song videos .. I watch blogs about what is happening in the world...), which is positive, but they also spend a lot of time playing games and satisfying private interests. Social worker practitioners emphasize that young people with mental disorders need support and control when using the virtual environment, as their primary interests are often related to access to various pornography websites, and their uncontrolled activities in the virtual environment can jeopardize the safety of young people with disabilities. It is therefore important to identify the potential risks associated with the use of social media and to identify the effective support, training or other resources needed to mitigate the risks (Raghavendra et al., 2015). The analysis of the focus discussions shows that some young people with disabilities are aware of the harmful effects of excessive use of the Internet, social networks and various sites on health and share their experience, indicating that .. I have headache and fatigue after a long time spent at the computer, leg hurts, ...., .. if I spend a long time at the computer, I have headache..., however, none of the respondents did not mention safety.

Young people with disabilities are more likely to mention social media such as Facebook, draugiem.lv, Youtube, Wikipedia, as well as specialized websites according to the type of disorder/disability, such as the websites with sign language. Everyone emphasizes the need for social contacts, which can be partly met by chatting, engaging in interest groups, and so on. Stationary and portable computers and telephones with internet connection are used more often than tablets.

In order to promote a positive media experience for young people with disabilities, greater collaboration between home and school is required, using assistive technology, training and support to learn how to use digital tools. 
Support is needed not only for young people with disabilities, but also for parents, carers and social service providers. This can take the form of learning how to use digital tools, knowledge on assistive technologies, knowledge and skills on how to integrate social media and assistive technologies into the daily lives of young people with disabilities. There are also discussions about involving young people with disabilities on social media platforms, which create opportunities for work in the online social media environment (Bloggers, Influencers), teleworking (more than half of the world's professions can be done remotely, such as telejob), access to services (services are available remotely), belonging (involvement in groups and interest groups, opportunities to form one's society in the digital environment), modern technological solutions (video chat and correspondence, platforms in education, work and everyday life) (Boitmane, 2019).

Research has limitations - only a small part participated in the questionnaire and focus discussions, moreover, those were the most active representatives of young people with disabilities, so the results involving, for example, young people with severe intellectual disabilities, young people with mobility impairments or visually impaired (blind) people may differ.

\section{Conclusions}

Young people with disabilities in Latvia involved in research use social media for education, socialization and entertainment. In order for young people with disabilities to focus more on educational and intellectually inspiring websites, support for the development of digital competence is needed. It should be differentiated, depending on the type of disability: it could be teleworking competence for a large part of people, acquisition of business competence, for people with mental disorders - receiving services remotely, involvement in interest groups, chat, etc., taking into account personal safety. Such support and education for people with disabilities should be provided from an early age, with an emphasis on the digital environment as a learning and working environment and an opportunity for self-control and self-development.

\section{Acknowledgment}

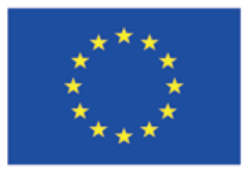

\section{Co-funded by the \\ Erasmus+ Programme of the European Union}

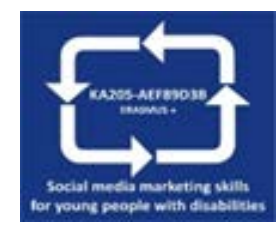

ERASMUS+ Strategic Partnership project "Social media marketing skills for fostering the inclusion and employability of young people with disabilities - SMM4WIN"

Nr. 2019-2-PL01-KA205-066133 


\section{References}

Balandin, S., \& Molka-Danielsen, J. (2015). Teachers’ perceptions of virtual worlds as a medium for social inclusion for adults with intellectual disability. Disability \& Rehabilitation, 37, 1543-50. doi: 10.3109/09638288.2015.1052574

Boitmane, I. (2019). Invalīdu profesionālā iesaiste sociālo mediju platformās. Retrieved from http://www.siva.gov.lv/tl_files/foto/koledza/Zinatniska_konference-

2019/2_Boitmane_Iesaiste-soc-med-platformas.pdf

Brunner, M., Palmer, S., Togher, L., \& Dann, S. (2019). "If I knew what I was doing on Twitter then I would use it more": Twitter experiences and networks of people with traumatic brain injury (TBI). Brain Impairment. DOI: https://doi.org/10.1017/BrImp.2019.12

Centrālā statistikas pārvalde (2019). Iedzīvotāju skaits republikas pilsētās, novadu pilsētās un novados. Retrieved from https://www.csb.gov.lv/lv/statistika/statistikas-temas/ iedzivotaji/iedzivotaju-skaits/galvenie-raditaji/iedzivotaju-skaits-republikas-pilsetas

Forrester-Jones, R., Jones, S., Heason, S., \& Di'Terlizzi, M. (2004). Supported Employment: A Route to Social Networks. Journal of Applied Research in Intellectual Disabilities, 17(3), 199-208. https://doi.org/10.1111/j.1468-3148.2004.00199.x

García-Betances, R. I., Cabrera-Umpiérrez, M. F., Ottaviano, M., Pastorino, M., \& Arredondo, M. T. (2016). Parametric cognitive modeling of information and computer technology usage by people with aging- and disability-derived functional impairments. Sensors (Basel, Switzerland), 16(2), 266. DOI: https://doi.org/10.3390/s16020266

Hemsley, B., Balandin, S., Palmer, S., \& Dann, S. (2017). A call for innovative social media research in the field of augmentative and alternative communication. Augmentative and Alternative Communication, 33(1), 14-22. DOI: 10.1080/07434618.2016.1273386

Koskentausta, T., Iivanainen, M., \& Almqvist, F. (2007). Risk factors for psychiatric disturbance in children with intellectual disability. Journal of Intellectual Disability Research, 51, 43-53. DOI: 10.1111/j.1365-2788.2006.00871.x

Labklājības Ministrija (2019). VDEĀVK uzskaitē esošās pilngadīgās personas ar invaliditāti pēc invaliditātes smaguma pakāpes un administratīvās teritorijas. Retrieved from https://data.gov.lv/dati/lv/dataset/vdeavk-pilngad-pers-ar-invaliditati

Luo, N., Zhang, M., \& Liu, W. (2015). The effects of value co-creation practices on building harmonious brand community and achieving brand loyalty on social media in China. Computers in Human Behavior, 48, 492-499. DOI: https://doi.org/10.1016/ j.chb.2015.02.020

Media Access Australia (2012). Sociability: Social media for people with a disability. Media Access Australia. Retrieved from http://www.mediaaccess.org.au/web/social-mediaforpeople-with-a-disability

Paterson, H., \& Carpenter, C. (2015). Using different methods to communicate: how adults with severe acquired communication difficulties make decisions about the communication methods they use and how they experience them. Disability \& Rehabilitation, 37, 1522 -1530. doi:10.3109/09638288.2015.1052575

Raghavendra, P., Newman, L., Grace E., \& Wood, D. (2015). Enhancing social participation in young people with communication disabilities living in rural Australia: outcomes of a home-based intervention for using social media. Disability and Rehabilitation, Volume 37, Issue 17: Special Issue: Social Media and Communication. https://doi.org/10.3109/09638288.2015.1052578 
Stendahl, K., \& Balandin, S. (2015). Virtual worlds for people with autism spectrum disorder: A case study in Second Life. Disability \& Rehabilitation, 37, 1591-1598. doi:10.3109/09638288.2015.1052577

Wang, Y., Min, Q., \& Han, S. (2016). Understanding the effects of trust and risk on individual behavior toward social media platforms: A meta-analysis of the empirical evidence. Computers in Human Behavior, 56, 34-44. DOI: https://doi.org/10.1016/ j.chb.2015.11.011

Wang, W., Wu, Y., Yuan, C., Xiong, H., \& Liu, W. (2017). Use of Social Media in Uncovering Information Services for People with Disabilities in China. International Review of Research in Open and Distributed Learning. Special Issue: Advances in Research on Social Networking in Open and Distributed Learning, Volume 18, Number 1. Retrieved from https://www.erudit.org/en/journals/irrodl/1900-v1-n1-irrodl05016/1066179ar.pdf 